\title{
2011
}

Working Paper

1 5

INSTITUTO DE POLÍTIGAS Y BIENES PÚBLIGOS [IPP]

\section{FACTORS INFLUENCING THE LOCATION OF NEW \\ MOTORWAYS: THE LARGE SCALE MOTORWAY BUILDING IN SPAIN}

\section{AdelHeid Holl}

CONSEJO SUPERIOR DE INVESTIGACIONES CIENTÍFICAS (CSIC)

Institute for PUblic Goods ANd Policies (IPP) 


\section{INSTITUTO DE POLÍTICAS Y BIENES PÚBLICOS CCHS-CSIC}

Copyright $@ 2011$. Holl, A. All Rights reserved.

Do not quote or cite without permission from the author.

Instituto de Políticas y Bienes Públicos

Centro de Ciencias Humanas y Sociales

Consejo Superior de Investigaciones Científicas

C/ Albasanz, 26-28.

28037 Madrid (España)

Tel: +34916022300

Fax: +34 913045710

http://www.ipp.csic.es/

The working papers are produced by Spanish National Research Council - Institute of Public Goods and Policies and are to be circulated for discussion purposes only. Their contents should be considered to be preliminary. The papers are expected to be published in due course, in a revised form and should not be quoted without the authors' permission.

\section{How to quote or cite this document:}

Holl, A. (2011). Factors influencing the location of new motorways: the large scale motorway building in Spain. Instituto de Políticas y Bienes Públicos (IPP), CCHS-CSIC, Working Paper, Number 5.

Available:http:/hdl.handle.net/10261/34855 


\title{
FACTORS INFLUENCING THE LOCATION \\ OF NEW MOTORWAYS: THE LARGE SCALE MOTORWAY BUILDING IN SPAIN
}

\author{
ADELHEID HOLL \\ CONSEJO SUPERIOR DE INVESTIGACIONES CIENTÍFICAS (CSIC) \\ InSTITUTE FOR PUblic GoOds AND POLICIES (IPP-CCHS) \\ A.HOLL@CSIC.ES
}

\begin{abstract}
Since the 1980's Spain has developed an ambitious road building programme with the construction of approximately 12,000 kilometres of new motorways. This article analysis the factors related to the placement of these new motorways during two distinct planning periods from 1983 to 1993 and 1994 to 2004.
\end{abstract}

Keywords: infrastructure, motorways, placement.

JEL classification: R42; R53; R58

\section{CONTENTS}

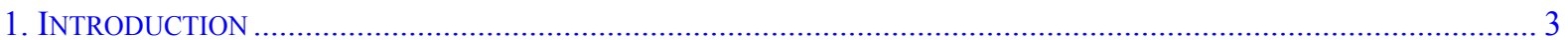

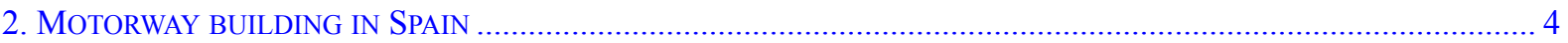

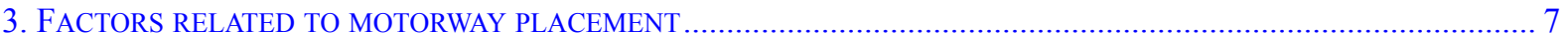

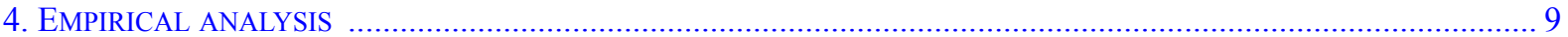

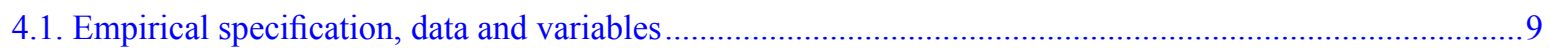

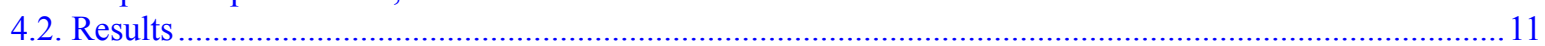

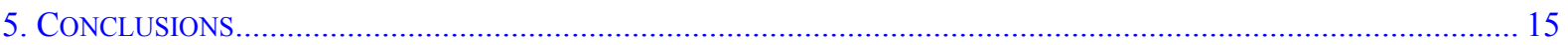

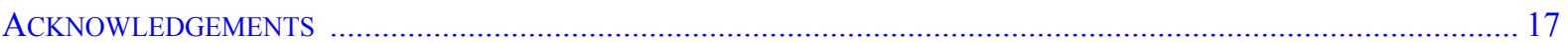

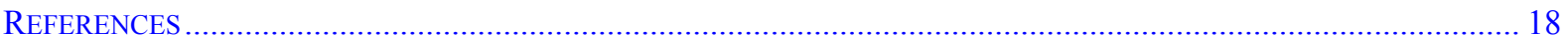




\section{INTRODUCTION}

Since the 1980s Spain has developed an ambitious motorway building programme extending the network by about 12,000 kilometres and bringing the total length of motorways up to 14,021 $\mathrm{km}$ in 2009. ${ }^{1}$ Today, Spain has the longest motorway network among EU countries and has more motorway kilometers per capita than France, Germany, the UK, or Italy.

An extensive literature has examined the relationship between infrastructure investment and economic development (see, for example, Gramlich, 1994; de la Fuente, 2010; Lakshmanan, 2011 for reviews of this literature). There is also a large literature that has focused specifically on the spatial development impacts of motorway building. For the US interstate highway network, Moon (1988, 1994), for example, provided an account of the development of the network and land-use impacts. Chandra and Thompson (2000) studied the earnings impacts of interstate highways in US non-metropolitan counties. Baum-Snow (2007) assessed the extent to which interstate highways have contributed to the decline of central city population in US metropolitan areas. Duranton and Turner (2010) estimated the effect of interstate highways on the growth of US cities. For the UK, Linneker and Spence (1992 and 1996) studied the relationship between regional employment and accessibility changes due to the construction of the M25 London orbital motorway. Holl (2004a, 2004b) examined whether new motorway construction in Spain and Portugal during the 1980s and 1990s influenced firm location and relocation. Garcia-López (2010) analysed the role of access to motorways for population location and land consumption patterns in the metropolitan area of Barcelona.

Compared to the large body of literature on the economic impacts of infrastructure investment, much less is known about the determinants of infrastructure investment in general and on the factors related to motorway placement more specifically. Rietveld and Boonstra (1995) studied the supply of railways and highways among different European regions and concluded that the supply of infrastructure depended mainly on regional population size and the gross domestic product in the pertaining country. Van de Walle (2002) studied how rural road investments in Vietnam were selected. Herranz-Loncán (2007) provided a historical study of the spatial distribution of transport infrastructure in Spain between 1860 and 1930. Furthermore, a range of studies analysing the allocation of public funds have shown that governments may follow different objectives in the distribution of investment across jurisdictions (De la Fuente and Vives, 1995, de la Fuente, 2001, 2004; Yamano and Ohkawara, 2000; Castells and Solé-Ollé, 2005; Cadot et al., 2006; Kemmerling and Stephan, 2008; Golden and Picci, 2008; Solé-Ollé 2009).

A better understanding of the placement process is not only important on its own, but is crucial for correctly assessing the impacts of transport infrastructure investment on spatial economic development. The specific nature of the relationship between transport infrastructure and economic development and the strength of the influences is still subject of an ongoing debate.

1 Motorways in Spain are autovías (free motorways) and autopistas (toll motorways). 
This paper presents an analysis of the factors related to the allocation across space of motorways in what can be termed the construction of Spain's primary motorway network during the period of 1983-2004, forming the backbone of the Spanish road network. The existing literature on the allocation of infrastructure investment has mainly focused on the inter-regional distribution of investment. This article differs from this literature by providing an exploratory study at a more detailed spatial level (the municipality) and of a specific type of investment, namely motorways. Furthermore, the investment process is related directly to the different road building plans. The aim is to explicitly analyse the process driving the placement of new motorways both in the actual networks constructed as well as in the major national road building plans that were drawn up.

\section{MotorWAY BUILDING IN SPAIN}

At the beginning of the 1980s the total extension of the motorway network in Spain amounted to just under 2,000 kilometres (Figure 1). These were primarily toll motorways built in the late sixties and seventies in the Valle de Ebro corridor and along the tourism zones of the Mediterranean coast. After years of stagnation, during the sixties the country experienced strong economic growth accompanied by a rapid increase in car ownership and road traffic, leading to an unsustainable situation given the poor state of the main road network. According to Bel (2010) the two corridors where the early toll motorways were built were those with the strongest growth in economic activity and heavy traffic. The country's growth process was, however, interrupted by the oil crises of the seventies, which brought to a halt the brief investment process in road infrastructure. At the beginning of the eighties, Spain then showed a clear deficit in road infrastructure. Compared to other European countries, Spain lagged markedly behind in terms of its motorway network due to its historically lower road investment (Borrajo, 1988).

Since then the motorway network has been extended by about 12,000 kilometres, bringing its total length up to $14,021 \mathrm{~km}$ in 2009 (Figure 1). The network now provides access to all mainland Autonomous Regions and at the time of writing to all but one provincial capital (where construction is currently under way), converting it to effectively the longest motorway network among EU countries. No other European country has experienced such massive motorway construction in such a short period of time.

This has been achieved through different national road construction plans. With the transformation of the Spanish state from a centralized model to one of Autonomous Regions, the ownership of roads was redefined at the beginning of the 1980s. The state road network managed by the central government was defined as routes of general interest that guarantee inter-community and international connections, access to ports, airports of general interest and main border crossings. These represented about $25 \%$ of the totality of main roads but supported most of the traffic (Borrajo and Rubio, 1987). Depending on their functionality, other roads were transferred to the Autonomous Communities, provinces, and municipalities. 
With the aim of improving traffic conditions in the state road network, the "Plan General de Carreteras" (National Road Plan) was drawn up in 1983 (Figure 2). Implementation started in 1984, with the programming phase covering the period up to 1991. The plan strongly followed the existing radial road network which dates back as far as the eighteenth century, as illustrated in Figure 3 showing a map by Thomas Lopez from 1760 with the principal designated post routes (Menéndez-Pidal, 1992). ${ }^{2}$

The main objective of the National Road Plan was to relieve the traffic situations in the most congested corridors. Most of them where the radial routes linking the major cities to the capital, Madrid. ${ }^{3}$ The basic strategy adopted was to upgrade the principal road connections to free motorways by widening and adding new lanes. Using the existing lanes implied approximately a third of the cost of the construction of an entirely new motorway (Borrajo, 1985). This was a determining criterion, since the plan was drawn up in a period that was still characterised by economic recession and thus important budget constraints. The situation, however, changed in the second half of the eighties when the economy started to grow again. This coincided with Spain's entry into the European Community and funding, first from the EU Regional Funds, and later from the EU's Cohesion Fund becoming available. This meant that gradually the construction changed from the "doubling of lanes approach" to the construction of new segments which also allowed higher technical and safety standards. Overall, however, 70 percent of the planned motorways during this phase involved the conversion of an existing national trunk road to a motorway by a doubling of existing lanes (Borrajo and Rubio, 1986). Examples are the A4 Southern motorway from Madrid to Sevilla that follows the former national trunk road N-IV or the A42 between Madrid and Toledo being an upgrading of the N401 trunk road. The remaining 30 percent of motorways built during this period were newly built but, in general, also closely followed the itinerary of the existing main trunk roads. The plan was finished and made public in 1984, the same year as implementation of the plan started. However, it was not until the late 1980s that the first important motorway links of this major road building programme opened to traffic and the end of 1993 that the motorway connections that had been planned were finished. Overall, the motorway connections built during this period corresponded quite accurately to those set forth in the plan (Borrajo and Rubio 1992).

In 1993, the government introduced the "Plan Director de Infraestructuras 1993-2007" (PDI - Infrastructure Master Plan) that was to complete the construction of the primary motorway

2 King Carlos III (1716-1788) in 1761 ordered the construction of radial roads linking "as direct as possible" Madrid to Valencia, Andalusia, Catalonia and Galicia in what can be considered the first national road building plan. Later, routes to Extremadura and the Basque Country were also included, the latter linking to France. Together, these are the precursors of the six radial motorways of the current Spanish road network.

3 Some non-radial itineraries also supported high traffic intensity, such as, for example, the Vale de Ebro corridor or the Mediterranean corridor, where the first toll motorways have been built. Other main itineraries with high traffic intensity that were not prioritized in this plan were, for example, the non-radial itinerary between Santander and Oviedo in the North, or Cadiz-Algeciras in the South, as well as Benavente-La Coruña and Benavente-Ourense-Vigo connecting the centre to Galicia. 
network initiated in the National Road Plan (Figure 4). The plan was approved in Parliament in March 1994 and aimed at infrastructure improvement in general but with interurban transport infrastructure amounting to $57 \%$ of the total infrastructure investment planned. While the modernization of the rail network formed a central part of the plan, the resources devoted to roads continued to constitute the largest part. The PDI envisioned a network of motorways of about $11,000 \mathrm{~km}$ at the end of the planning period. Rather than a plan in its strict sense, it has to be considered as an Esquema Director (Directive Scheme) similar in spirit to the Schéma Directeur in France (Borrajo and Rubio, 1991). Compared to the previous National Road Plan it was much more general with a considerably longer time horizon, with no specific timing for construction or specification of financing.

In 2000 the PDI was replaced by the Plan de Infraestructuras (2000-2007). One of its key objectives was to extend the motorway network up to $13,000 \mathrm{~km}$ by 2010 and to facilitate the integration of the high capacity network in the trans-European road network with new connections to Portugal and France both by road and rail. During the nineties, goods transport between Spain and the rest of Europe greatly increased, with roads absorbing about $80 \%$ of these transport flows. This implied that traffic through the Pyrenean border crossings heavily increased, though infrastructure in this area up to that time had seen relatively few improvements (López and Sánchez, 2001).

The main planning instrument currently in place is the Plan Estratégico de Infraestructuras $y$ Transporte 2005-2020 (PEIT - Strategic Plan for Infrastructures and Transport). With the PEIT investment in transport infrastructure continues to be a priority of the government although the main weight is now shifting to high-speed rail. Furthermore, concepts of sustainability and intermodality have been included in this plan. As for the high-capacity road network the plan still includes more than $5,000 \mathrm{~km}$ of new motorways mainly through the provision of a complementary finer mesh network that is aimed to break the strongly radial nature of the existing network by giving priority to the completion of connections that join cities without going through Madrid. Examples are the A66 North-South motorway in western Spain running from Gijón to Sevilla, the A8 on the Northern Coast of Spain, the A62 between the Portuguese border and Salamanca, or the A-43 that will connect the western Extremadura region with the east of Spain. It is the political goal to link all the 47 mainland provinces and important cities to motorways. Traffic intensity in many of these itineraries is, however, below the usual standards for the construction of four-lane motorways (ECORYS, 2006).

Today, the road system in Spain is highly developed. Indeed, Spain has now one of the longest motorway networks among EU countries. In the future, their will be important issues regarding the maintenance of this vast network. On the one hand, the earlier parts of the network in particular were built with lower quality standards and will thus have higher maintenance costs in the future. On the other hand, most of the latter additions to the motorway network, especially the more recent toll motorway constructions, carry very low daily traffic intensities. The AP7 toll motorway between Cartagena and Vera, for example, is called the "ghost motorway". 
The AP41 Madrid-Toledo motorway is in a similar situation with annual average daily traffic in 2009 below 2,000 vehicles (FOMENTO, 2009a). ${ }^{4}$ In many of these cases there exists an alternative free motorway and the time gained using the toll motorway is not enough to shift a substantial number of drivers to the toll road. A similar situation is happening in the Madrid metropolitan area where several radial toll access motorways have been built based on overly optimistic traffic forecasts and have failed to reach their forecasted traffic volumes. The current economic crisis has further reduced traffic in general on the toll network. This now bears on the financial viability of the concessions with low traffic intensity and their ability to maintain the infrastructure.

While intermodality is featured in the current infrastructure policy, freight transport in Spain is strongly dominated by roads and the motorway network is still characterised by a lack of adequate integration with ports and railways. In urban areas there is a need to ensure integration with other public transport modes. With the increasing density of the motorway network, environmental considerations will certainly also become more prominent in the future. ${ }^{5}$ To date, there has been relatively little opposition to motorway construction. Although in some specific motorway segments crossing environmentally protected areas, such as for example, the A381 Jerez to Algeciras motorway or the M501 motorway in the western Madrid region, there has been protest from environmental groups. In the case of the N433 national trunk road between Sevilla to Rosal de la Frontera on the Portuguese border plans on behalf of the Ministry of Public Works to build a motorway were opposed by the local population and the project has been abandoned given its high environmental impact and the anyway relatively low traffic intensity of the itinerary for a motorway.

\section{FACTORS RELATED TO MOTORWAY PLACEMENT}

Roads are not built randomly. Networks are designed to connect the major cities and economic centres of a country and this was certainly the key consideration in the Spanish motorway building programmes. Nevertheless, how decisions are made about specific routes and the priority such routes are given in a specific investment program, is an open question.

Studies analysing the allocation of infrastructure investment show that governments may follow different objectives in the distribution of investment across jurisdictions (Yamano and Ohkawara, 2000; Cadot et al., 2006; Kemmerling and Stephan, 2008; Golden and Picci, 2008). For Spain, a number of studies have analysed the inter-regional allocation of infrastructure

4 In comparison, toll motorways supported on average about 21,020 daily vehicles and free motorways about 26,040 daily vehicles in 2009 (FOMENTO, 2009b).

5 Moreover, while the first free motorways were by and large upgradings of existing infrastructure, later additions have included more greenfield stretches which imply greater environmental impacts. In this context, for example, the toll motorway project between Toledo and Cordoba passing through environmentally protected areas was stopped because it did not pass its environmental impact assessment. 
investment (de la Fuente and Vives, 1995, 2001, 2004; Castells and Solé-Ollé, 2005; SoléOllé, 2009). This literature has developed different theoretical approaches to model the relevant decision-making processes and in general distinguishes efficiency versus equity considerations as the main economic rationales for the allocation of investment. According to the efficiency criterion one would expect investment to be highest in those regions where its marginal productivity is highest. As de la Fuente and Vives (1995) show for Spain, the expected return is highest in regions with higher income levels and higher effective infrastructure endowment. Thus, following the efficiency criterion, one would expect higher investment in richer regions. According to the regional equity criterion, the goal would be to equalize effective infrastructure endowment, thus, regions with the lowest infrastructure endowment would be targeted and these are in general the poorest regions. Spain's 1978 Constitution introduced a territorial organisation and with it an important process of political decentralisation and an emphasis on policies to enforce territorial equity (De la Fuente and Gundin, 2008). At the same time, infrastructure investment has also been justified as regional development aid (Hart, 1993). This is based on the view that income disparities are primarily caused by regional disparities in the endowment of key factors of production. As a result, one would expect the regions with the lowest income levels to be targeted. EU funds, particularly those targeting Objective 1 regions, are strongly based on the regional development rationale and they have also conditioned the spatial distribution of infrastructure investment in Spain towards less developed regions (SoléOllé 2009). ${ }^{6}$

Regarding the empirical evidence for Spain, de la Fuente and Vives (1995) analysed investment allocation during the 1980s and found a positive effect for expected return and a negative effect for income. They concluded that both efficiency and equity considerations played a role but that efficiency was probably of greater weight. De la Fuente (2001) found similar results for the period up to 1995. De la Fuente (2004) showed that there existed a clear trade-off between efficiency and equity considerations and concluded that public investment in Spain was actually exceeding the optimal degree of redistribution.

The political economy literature emphasizes that politicians may also use the allocation of investment as a reward for loyalty and for vote seeking. Burgess et al. (2010) showed for Kenya how politicians favour regions of their own ethnic background in terms of road investments. For Spain, de la Fuente and Vives (1995) found little evidence of political influence in infrastructure investment decisions during the 1980s. In contrast, Castells and Solé-Ollé (2005) and SoléOllé (2009) considered the periods 1987-1996 and 1964-2004 respectively and argued that political considerations had influenced the inter-regional allocation of infrastructure spending in Spain. Solé-Ollé (2009) distinguished redistribution based on electoral considerations from redistribution that could be linked to specific criteria and rules such as the use of investment as

6 Moreover, since the 1990s, EU transport policy, as another factor in motorway placement, started to play a role with the development of the Trans-European Transport networks (TEN-T). Among the TEN-T priority axes is, for example, the Multimodal axis Portugal/Spain-rest of Europe. 
an instrument of regional policy. He found empirical evidence for both. Bel (2010) argued that infrastructure policy in Spain had been used by the central government for nation-building and had not been driven by the requirements of the economic system.

Table 3 summarizes the main criteria that planners involved in the Spanish national motorway building programmes used in multicriteria analyses in comparing alternative routes (Rubio and Borrajo, 1990, 2000). The economic criteria refer to the monetary costs and benefits related to each alternative. Economic appraisal of projects is aimed at helping to select the projects which will generate greater net benefits than their alternatives. In practice, the measurement of net benefits is, however, complex and faces many practical problems (value of time, appropriate rate of discount, indirect economic impacts, network effects, etc.), particularly in the case of largescale infrastructure projects (Vickerman, 2007). In terms of socio-economic criteria, planners also considered the population covered by the corridors of each alternative, mean income in the provinces crossed compared to the national average income, the tourism potential of the area and the existence of other infrastructure of general interest such as ports, airports, and national border crossings. Territorial criteria that planners included in multi-criteria analyses were the accessibility of the crossed region, whether the route forms part of the principal national high capacity road network and the international road network, and indicators related to territorial equality in terms of mean income and existing major road infrastructure. All of the plans mentioned included reductions in territorial disparities as a direct policy goal, and investment in transport infrastructure as an essential instrument to achieve greater cohesion.

These criteria form only one element of the decision making process, the final decision being political. As Short and Kopp (2005) argued based on the experience of the European Conference of Ministers of Transport, "considerable distance remains between planning outcomes on the one hand and policy decisions and implementation on the other" (p. 360).

\section{EMPIRICAL ANALYSIS}

\subsection{Empirical specification, data and variables}

In order to analyze the factors that are correlated with receiving a new motorway, several linear probability models are estimated where the dependent variable $\mathrm{M}_{\mathrm{it}}$ equals 1 if municipality $\mathrm{i}$ gained a motorway within its municipality radius during the planning period t and 0 otherwise. ${ }^{7}$

$$
p_{i t}=p\left(M_{i t}=1\right)=\beta_{1}+\beta_{2} X_{i t}
$$

where, $X_{i t}$ is a vector of observable variables as described below. ${ }^{8}$

$7 \quad$ The radius is calculated for each municipality individually by approximating its surface within a circle area. While the average size of municipalities in mainland Spain is about 60 square kilometres, the values range from $0.03 \mathrm{~km}^{2}$ in the case of Emperador a small municipality in the Autonomous Community of Valencia to Cáceres the largest municipality with $1750 \mathrm{~km}^{2}$; the radius varies accordingly.

8 Since the dependent variable is discrete, a drawback of the linear probability model is that it does not 
Two periods are distinguished. First, the planning period of the National Road Plan which covers the years from 1983 to 1993, and secondly, the period from 1994 to 2004 which covers the period of the PDI and the Plan de Infraestructuras which replaced the PDI in its second programming phase. The current PEIT started in 2005 and does not form part of the present analysis.

The sample for all estimations includes all those municipalities that received a new motorway within the radius of their municipality in the respective period and all those municipalities that had no motorway at the beginning of the period and did not receive one.

A number of right-hand side variables that are potentially correlated with the spatial allocation of motorways are included based on the literature about the allocation of public funds and the planning considerations discussed in the previous section.

The existence of a trunk road within the municipality radius (trunkroad) before the start of the planning period will reflect cost issues. The variable is constructed as a dummy variable taking on the value of 1 for municipality $i$ if the distance to the nearest trunk road is less than the approximated municipality radius of municipality i. Particularly during the first major planning period, the policy was to take advantage of the existing lanes of major trunk roads in order to save on costs. ${ }^{9}$ The existence of a major trunk road, however, also reflects existing demand.

Demand is further proxied by the overall population accessibility level (access) which captures the main population centres and corridors linking those centres. It is calculated as own population plus the distance discounted sum of population to the largest 568 Spanish mainland municipalities, where the distance is measured in travel time along the existing real road network before the start of the respective planning period. ${ }^{10}$

These two variables proxy cost and demand dimensions and indicate the degree to which efficiency criteria have influenced the placement of motorways. ${ }^{11}$

Total municipality population ( $(p o p)$ is included to capture the size of municipalities. In addition a dummy variable indicating whether or not the municipality forms part of a major urban agglomeration (dagglom) is also included.

Dcoast is a dummy that equals one for all municipalities that are within 10 kilometres of the coast. This is aimed at capturing the tourism potential mentioned in the planning documents.

Other variables related to socio-economic conditions include province income per capita

restrict the predicted value to lie within the $(0,1)$ interval. Thus, logistic regressions have also been carried out. Results are qualitatively unchanged and are available upon request.

9 The existing trunk road network will also account for topography. Features such as mountains and valleys strongly influence the structure of networks, as well as the cost and feasibility of new projects.

10 Holl (2007) provides an illustration and further details.

11 Calculating the expected return of each investment would be beyond the scope of this paper and would, in any case, not be possible at the municipal level due to lack of consistent data sets at this geographically detailed level. 
relative to the national average ( $\left.g d p \_c a p i t a\right)$, mean province accessibility relative to the national average (access_prov), as well as province transport infrastructure capital stock relative to the average province transport infrastructure capital stock (infra_capital).

Finally, the average annual population growth rate ( $p o p \_$growth) and GDP growth rate ( $g d p_{-}$ growth) over the years prior to the plans coming into effect are included to test how motorway placement is related to prior growth conditions.

Table 2 summarises the definitions of the variables and data sources. In addition, dummy variables for Autonomous Communities are included. Not only could political factors influence the placement decision regarding national motorways (vote gaining, political affinity with the central government, or their lobbying capacity) as shown by Castells and Solé-Ollé (2005) and Solé-Ollé (2009), most Autonomous Communities have developed their own road building programmes in response to the National Road Plan and the decentralization of the Spanish state outlined in the 1978 Constitution and the subsequent transfer of responsibility for roads of regional importance.

\subsection{Results}

Table 3 shows the results for the probability of receiving a motorway during the first period of 1983 to 1993 which coincides with the National Road Plan. In column (1) only the trunkroad variable is included together with the region dummies. The trunkroad variable is positive and highly significant. The unreported region dummies are mostly not significant, nor are they jointly significant. The adjusted $\mathrm{R}^{2}$ is around $44 \%$ with their inclusion and about $42 \%$ if they are omitted. This shows a strong explanatory power for the trunkroad variable and reflects the fact that the motorway construction strongly followed the existing main road network. In columns (2) to (6) the other socio-economic and territorial variables are added. Overall, a look at the adjusted $\mathrm{R}^{2}$ shows that conditional on the existing trunk road network, other variables show only small increases in the model fit.

The population accessibility variable and the municipality size as well as the dummy for urban agglomerations all show a positive and significant effect and indicate that the motorways were indeed located in order to link the major urban agglomerations (column 2). It also reflects that specific corridors are planned in order to capture a maximum amount of population. The dummy for municipalities located within 10 kilometres from the coast shows a negative effect (column 3 ). During this period the construction of motorways was mainly guided by the development of a radial network linking the capital Madrid to the other main economic centres, thus the negative relation to coastal location. Column (3) also includes the GDP per capita in the province relative to the national average. Because regressing individual variables on aggregate variables, such as the province income level, could induce a downward bias in the estimation of standard errors, the standard errors reported in column (3) to (6) are based on Moulton's correction (Moulton, 1990). 
The GDP per capita variable shows a positive effect that is, however, not statistically significant. Richer regions generate more traffic flows and thus a greater need for infrastructure investment. Moreover, the actual construction of motorways analysed here also includes motorways built by the regional governments, such as, for example, the C16 motorway between Barcelona and Manresa, the $\mathrm{C} 17$ motorway between Barcelona and Vic, the M40 ring motorway in Madrid, the A10 motorway in Navarra, or the A92 motorway between Sevilla and Guadix among others, and the richer regions have more resources to invest in their road networks. On the other hand, under the redistribution or regional development aid criteria one would expect a negative relation to the initial income level. In a much longer time series analysis, de la Fuente (2008) found a positive correlation between the average regional growth rate in the stock of infrastructure and the initial income level, but a negative correlation if the growth rate was measured per capita. He argued that the strong population growth in many of the richer regions meant that those regions lost in relative terms in their infrastructure endowment per capita compared to some poorer regions. In column (4), the average province accessibility level relative to the national average is added. This variable shows no significant correlation with receiving a motorway at the municipality level, nor does the province transport infrastructure stock variable added in column (5). ${ }^{12}$ Together, these results suggest that the actual placement of motorways during the period of the First National Road plan was not directly related to equity or redistribution.

Finally, in column (6) prior population and GDP growth are added. Neither of the two is statistically significant. At the regional level, the study by Castells and Solé-Ollé (2005) for 1987-1996 found that regional infrastructure capital investment responded positively to lagged regional population growth as well as lagged regional output growth. For the period considered here, this has not been the case for motorway placement at the local level, once other considerations such as an existing main trunk road or the size of the municipality and more in general, the specific location of the municipality in relation to the road network and the urban system are taken into account.

Table 4 shows the results for the probability of receiving a new motorway between 1994 and 2004 coinciding with the PDI and the Plan de Infraestructuras. In comparison to Table 3, several issues are interesting to note. First, the adjusted $\mathrm{R}^{2}$ for the second period is significantly lower than for the first period. Estimations that only include the trunkroad variable yield an adjusted $\mathrm{R}^{2}$ of about $26 \%$ compared to around $42 \%$ for the first period. Thus, one of the main differences in the second period is that an existing trunk road within the municipality radius explains less than in the first period. Overall, this is a reflection of the change from the "doubling of lanes" policy to the construction of entirely new motorways in the later period. ${ }^{13}$ However,

12 The initial province transport infrastructure stock shows a high correlation with the initial province income level, but even if the latter is dropped from the estimations, the coefficient of the province transport infrastructure stock variable remains insignificant.

13 In other cases, such as the A381 Jerez-Algeciras motorway built by the regional government, the itinerary of the new motorway largely followed the existing regional C440 road forming part of the secondary road network and connecting the two cities. 
the location of a municipality in the vicinity of the initial trunk road network of the early 1980s is still a dominating factor related to the probability that a municipality gained a new motorway later on. Second, unreported regional dummies are now individually and jointly significant. This could, on the one hand, reflect the fact that this second mayor road building plan was much more general in nature and thus probably more open to the political influence of regional governments lobbying for the inclusion of motorways in their regions. On the other hand, since the regional GDP per capita relative to the national average is not statistically significant at conventional levels, the region dummies could be picking up different investment rates in the motorway networks by regional governments. Third, the average province accessibility level relative to the national average is now negative and statistically significant. This provides some evidence for equity considerations in the second period, at least in terms of narrowing spatial inequality in accessibility. Fourth, prior local population growth is now statistically significant indicating that motorway placement was positively related to prior local population growth during this period.

Because the actual construction and placement of motorways analysed here includes motorways built by regional governments and these have been mostly, on the one hand, in wealthier regions and, on the other hand, in the vicinity of the major urban agglomerations, the results will be compared to estimations without municipalities in major urban agglomerations. Before commenting on this, estimations are carried out for the planned networks.

Table 5 and 6 show the results from estimations that use the planned motorways instead of the actually constructed network in the respective planning period. Correlations of the planned networks with the actual networks show that in the first period the two coincide by $80.7 \%$, while in the second period the correlation is significantly lower at about $57.2 \%$. The following analysis shows how far the plans are actually related to the factors analysed.

Table 5 shows the results for the first planning period from 1983 to 1993. Compared to the actual constructions analysed in Table 3 , it is interesting to note the higher explanatory capacity of the model. At around $50 \%$, the factors analysed show a high explanatory power for the planned network. As before, the single most important factor by far is the existence of a principal trunk road in the vicinity of the municipality. Again, other factors improve the model fit very little. Nevertheless, some differences are worth pointing out. Municipalities in major urban agglomerations do not show a higher probability of receiving a new motorway in the plan but did so in the actual constructions. Again this points to investments of regional governments in their major agglomerations. The GDP per capita variable, the average province accessibility, and the initial province transport infrastructure stock also shows no significant relation to the planned network. Thus it appears that the plan did not favour specifically poorer regions once other factors are controlled for. Finally, as with the actually constructed network, no significant relation between prior population and economic growth and the planned network is shown.

Table 6 shows the results for the second major planning period of 1994-2004. In contrast to 
the first major planning period, the factors analysed now explain slightly less for the plan than for the actual constructed network. As with the actual construction during this period, the unreported regional dummies are in most cases individually and jointly significant. Together with the lower explanatory power of the model, this supports the view that this second major plan was more open to political influences. Again, one can see that municipalities in major urban agglomerations show no higher probability of receiving a new motorway in the plan but did so in the actual construction of the network. This second major road building planning phase also shows no significant relation to initial provincial income level nor to initial infrastructure endowment. However, as with the actual constructions during this period, province average accessibility relative to the national average shows a statistically negative correlation with the probability of receiving a new motorway. Moreover, at the local level prior population growth is not only related to actual construction but also to the planned construction during this period. In contrast, prior economic growth in the province has no significant relationship to the placement of new motorways.

As pointed out before, the actual construction and placement of motorways includes motorways built by regional governments. The results in Tables 3 to 6 indicate that one of the main differences between the plans and actual construction have been in the major urban agglomerations. Construction in these areas may have followed different criteria. ${ }^{14}$ Thus, as a robustness check, all estimations have been repeated without the municipalities in major urban agglomerations. Results are qualitatively unchanged if only municipalities in the major 24 agglomerations with a population of more than 150.000 inhabitants are dropped from the estimations. If a wider set of the 138 largest urban areas defined by the AUDES methodology is used, the results remain qualitatively unchanged for the actual constructions in the first period and the results change only slightly for the estimation of the planned network for the period 1983-1993. Here, the dummy for distance to the nearest coast is no longer significant. Both for the actual and planned network in the second period, prior population growth is not significantly related to the probability of receiving a new motorway outside these urban areas. ${ }^{15}$

In another robustness check, a dummy for municipalities that have an airport, a dummy for those that have a seaport, and a dummy for international border crossings have been included. The existence of other transport infrastructure was one of the criteria considered by planners (Table 2). Indeed, receiving a motorway in both periods is positively related to the existence of an airport or seaport. However, these dummies are correlated and strongly related to municipality

14 In urban agglomerations, the placement of new motorways interacts with urban development plans. See, for example, Garcia-López (2010) for the interrelationship between motorways and urban development in the metropolitan area of Barcelona. In the Madrid region, the "R" radial toll motorways which were constructed parallel to the main free access motorways form, along with the orbital motorways, a complex motorway network that interacts with land use change and new urban developments along the main motorways extending far from the city centre. As pointed out by one anonymous referee, in urban areas, decisions about motorway access points also play an important role in the interaction with urban development and further traffic generation.

15 For the AUDES methodology see: http://alarcos.esi.uclm.es/per/fruiz/audes/index.htm. Estimation results are available upon request. 
size. Estimations that include the airport and seaport dummies individually, instead of the initial population size yield qualitatively similar results. For the first period, the dummies show a significant positive relation to receiving a new motorway in the actual construction and the plan. For the second period, both variables are not significant in the estimation of the actual constructions once other explanatory variables are included, and for the plan only the airport dummy turns out significant. The border crossing is never significant.

The results show that motorway placement has been strongly related to the existing trunk road network. In this sense, the Spanish motorway building programmes show specific characteristics insofar as: a) many of the first new free motorways built in the eighties actually took advantage of the old road for one direction, building parallel running two lanes for the traffic in the opposite direction , b) even newer motorways often run in very close proximity to the existing infrastructure, keeping the old road as service lane or for local traffic, and c) the radiality of the network actually dates back as far as the eighteenth century. Indeed, the placement of the motorways analysed is significantly correlated with the distance from the 1760 postal routes as shown in Figure 3. In an alternative specification, the trunk road variable has been replaced with the distance from the 1760 postal route network shown in Figure 3. Motorway placement is negatively correlated with this distance; i.e. the further away a municipality is from these historic postal routes, the lower the probability of receiving a new motorway. The effect is particularly pronounced for the first National Road Plan that was strongly radial and primarily upgraded these routes dating back to the eighteenth century. ${ }^{16}$

\section{Conclusions}

This article has analysed the spatial placement of motorways in Spain covering a long period of more than twenty years during which the basic motorway network was developed. The analysis shows that the most dominant factor related to the probability of receiving a new motorway was an existing main trunk road. This illustrates well the critical role that past decisions play in the placement of new investment and the importance of the historic context. Population size and accessibility also were significantly related to the probability of a municipality receiving a new motorway. Municipalities in urban agglomerations showed a greater probability of receiving a new motorway in the actually constructed networks but not so in the national road plans. This indicates that regional governments have specifically complemented the national motorway network in their major urban agglomerations. Neither the plan nor the actual placement of motorways in the first period appears related to prior local or regional growth. For the second period, however, prior local population growth was positively related to both the plan as well as the actual construction in urban areas but not outside these areas.

The analysis in this article is of an exploratory nature illustrating the process of motorway 
placement in Spain. As transport routes condition the economic and social geography of a country, research about their placement is of basic geographic importance. It is also important for studies that aim to make causal inferences about spatial impacts of transport infrastructure investment. A pertinent problem in such studies is the potential endogenous allocation of such investment. In recent years, a growing body of literature has analysed impacts of transport infrastructure investment at the sub-national level related to issues such as population growth, urban sprawl, firm location or regional and local economic growth. The analysis in this article highlights those factors identified as significantly related to motorway placement and that therefore should be controlled for, as such factors may also have a direct effect on the specific impact under study. Overall, the results show that motorway placement in Spain has been primarily based on criteria related to the specific location of municipalities in the existing road network and the urban system, in other words, mainly fixed area characteristics. This was particularly the case for the first National Road Plan covering the period of the eighties and early nineties. There is little evidence that motorways were placed specifically where economic activity was expanding most.

Ultimately infrastructure investment is a political decision. The goal of the current PEIT, that all provincial capitals have at least one motorway connection is primarily political and not based on economic criteria. There are also numerous anecdotal examples of the influence of politics on the decision to build specific motorways, such as the motorway between Santiago de Compostela and Ourense, or the duplications of several toll motorways with parallel running free motorways being a response to the political pressure from those regions.

This article also shows that there are important differences between the first National Road Plan that covered the period from 1983 to 1993 and the plans that followed. The specific processes that drive the placement of new infrastructure are crucial and should be borne in mind when analysing transport infrastructure investment. 


\section{ACKNOWLEDGEMENTS}

Financial support from the Spanish Ministry of Science [SEJ2006-08063] and a Ramón y Cajal research contract is gratefully acknowledged. I am especially thankful to Justo Borrajo and Jesús Rubio for their kind support and provision of information and material and for interviews with Justo Borrajo in March 2010 and January 2011 and with Marta Rodrigo in February 2011. 


\section{REFERENCES}

1. Baum-Snow, N., 2007. Did highways cause suburbanization?, The Quarterly Journal of Economics 122, 775 805.

2. Bel, G., 2010. Infrastructure and nation building: The regulation and financing of network transportation infrastructures in Spain (1720-2010), IREA working paper 2010/16.

3. Borrajo, J., 1985. Las vías de gran capacidad: autopistas y autovías. Artículos de planificación de carreteras 1985.1: http://www.carreteros.org/planificacion/planificacion.htm

4. Borrajo, J., 1988. El proceso de planificación. Artículos de planificación de carreteras 1988.1: http://www. carreteros.org/planificacion/planificacion.htm

5. Borrajo, J., 2003. XVII Curso Internacional de Carreteras. Evaluación Coste/Beneficio. http://www.carreteros. org/planificacion/planificacion.htm

6. Borrajo, J. and Rubio, J., 1986. Seguimiento del Plan General de Carreteras y Planificación en las Comunidades Autónomas. Artículos de planificación de carreteras 1986.1: http:/www.carreteros.org/planificacion/ planificacion.htm

7. Borrajo, J. and Rubio, J., 1987. La Planificación de carreteras en España. Artículos de planificación de carreteras 1987.1: http://www.carreteros.org/planificacion/planificacion.htm

8. Borrajo, J. and Rubio, J., 1991. Una nueva planificación de carreteras: ¿un plan general o un esquema director? Artículos de planificación de carreteras 1991.1: http://www.carreteros.org/planificacion/planificacion.htm

9. Borrajo, J. and Rubio, J., 1992. Las carreteras en España. Artículos de planificación de carreteras 1992.2: http://www.carreteros.org/planificacion/planificacion.htm

10. Burgess, R., Jedwab, R., Miguel, E., and Morjaria, A., 2010. Our Turn To Eat: The Political Economy of Roads in Kenya http://mitsloan.mit.edu/neudc/papers/paper_294.pdf.

11. Cadot, O., Röller, L. H., and Stephan, A., 2006. Contribution to productivity or pork barrel? The two faces of infrastructure investment, Journal of Public Economics 90, 1133- 1153.

12. Castells, A. and Solé-Ollé, A., 2005. The regional allocation of infrastructure investment: The role of equity, efficiency and political factors. European Economic Review 49, 1165-1205.

13. Chandra, A., Thompson, E., 2000. Does public infrastructure affect economic activity? Evidence from the rural interstate highway system. Regional Science and Urban Economics 30, 457-490.

14. De la Fuente, A., 2001. Infraestructuras y política regional. Estudios sobre la Economía Española 122. FEDEA.

15. De la Fuente, A., 2004. Second-best redistribution through public investment: a characterization, an empirical test and an application to the case of Spain. Regional Science and Urban Economics 34, 489- 503.

16. De la Fuente, A., 2008. Inversión en infraestructuras, crecimiento y convergencia regional. Colección Estudios Económicos 20-08, FEDEA.

17. De la Fuente, A. and Gundin, M., 2008. El Sistema de Financiación de las Comunidades Autónomas de Régimen Común: Un Análisis Crítico y Algunas propuestas de Reforma. Investigaciones regionales 13, 213262.

18. De la Fuente, A. and Vives, X., 1995. Infrastructure and Education as Instruments of Regional Policy: Evidence from Spain. Economic Policy 10 (20), 13-51.

19. De la Fuente, A., 2010. Infrastructures and productivity: an updated survey, Mimeo, Instituto de Análisis Económico, CSIC, Barcelona.

20. Duranton, G, and Turner, M. A., 2010. Urban growth and transportation. Mimeo. http://individual.utoronto. ca/gilles/Papers/GrowthTransport.pdf

21. ECORYS Nederland BV. 2006. Study on Strategic Evaluation on Transport Investment Priorities under Structural and Cohesion funds for the Programming Period 2007-2013: Country Report Spain. Rotterdam.

22. FOMENTO 2009a. El tráfico en las autopistas de peaje. Ministerio de Fomento. Madrid.

23. FOMENTO 2009b. Anuario Estádistico 2009. Ministerio de Fomento. Madrid. 
24. Garcia-López, M.A., 2010. The Accessibility City. When Transport Infrastructure Matters in Urban Spatial Structure, Working Paper XREAP 2010-1.

25. Golden, M., Picci, L., 2008. Pork barrel politics in postwar italy, 1953-1994, American Journal of Political Science 52 (2), 268-289.

26. Gramlich, E.M., 1994. Infrastructure investment: A review essay, Journal of Economic Literature 32. 1147 75 .

27. Hart, T., 1993. Transport investment and disadvantaged regions: UK and European policies since the 1950s. Urban Studies 30, 417-436.

28. Herranz-Loncán, A., 2007. The spatial distribution of Spanish transport infrastructure between 1860 and 1930 , Annals of Regional Science 41:189-208

29. Holl, A., 2004a. Manufacturing location and impacts of road transport infrastructure: empirical evidence from Spain, Regional Science and Urban Economics 34, 341-363.

30. Holl, A., 2004b. Transport infrastructure, agglomeration economies, and firm birth: Empirical evidence from Portugal. Journal of Regional Science, 44, 693-712

31. Holl, A., 2007. Twenty Years of Accessibility Improvements. The Case of the Spanish Motorway Building Programme. Journal of Transport Geography 15 (4), 286-297.

32. Kemmerling, A. and Stephan, A., 2008. The polito-economic determinants and productivity effects of regional transport investment in Europe, European Investment Papers 13, 36-61.

33. Lakshmanan, T.R., 2011. The broader economic consequences of transport infrastructure investments, Journal of Transport Geography 9 (1) 1-12.

34. Linneker, B. and Spence, N., 1992. Accessibility measures compared in an analysis of the impact of the M25 London Orbital Motorway on Britain, Environment and Planning A 24,1137-1154.

35. Linneker, B. and Spence, N., 1996. Road transport infrastructure and regional economic development: The regional development effects of the M25 London orbital motorway, Journal of Transport Geography 4 (2), 77-92.

36. López A.M. and Sánchez, A., 2001. El plan de infraestructuras 2000-2007 del Ministerio de Fomento y su financiación: efectos económicos. Revista valenciana de economía y hacienda 3, 23-44.

37. Menéndez-Pidal, G., 1992. España en sus caminos. Caja de Madrid, Madrid.

38. Moon, H. 1988. Modelling land-use change around non-urban interstate highway interchanges. Land Use Policy 5 (4), 394-407.

39. Moon, H. 1994. The interstate highway system. Washington, D.C.: Association of American Geographers.

40. M.O.P.T., 1993. El Plan General de Carreteras: Realizaciones, Ministerio de Obras Públicas y Transportes, Secretaría General para las Infraestructuras del Transporte Terrestre, Madrid.

41. M.O.P.T., 1994. Plan Director de Infraestructuras: 1993-2007, Ministerio de Obras Públicas, Transportes y Medio Ambiente, Secretaría General Técnica, Madrid.

42. Moulton, B. R., 1990. An Illustration of a Pitfall in Estimating the Effects of Aggregate Variables on Micro Unit. The Review of Economics and Statistics 72(2), 334-338.

43. Rietveld, P. and Boonstra, J., 1995. On the supply of network infrastructure: Highways and railways in European regions, Annals of Regional Science 29, 207-220

44. Rubio, J and Borrajo, J, 1990. Un nuevo plan de carreteras urbanas e interurbanas. Artículos de planificación de carreteras 1990.1:

45. Rubio, J and Borrajo, J., 2000. VII Curso General de Transportes Terrestres. Plan o esquema Director. http:// www.carreteros.org/planificacion/planificacion.htm

46. Short, J. and Kopp, A., 2005. Transport infrastructure: Investment and planning, Policy and research aspects, Transport Policy 12, 360-367

47. Solé-Ollé, A., 2009. Inter-regional redistribution through infrastructure investment: Tactical or programmatic? Document de treball de l'IEB 2009/32. 
48. Van de Walle, D., 2002. Choosing Rural Road Investments to Help Reduce Poverty, World Development 30 (4), 575-589, 2002

49. Vickerman, R., 2007. Cost benefit analysis and large-scale infrastructure projects: state of the art and challenges. Environment and Planning B: Planning and Design 34, 598-610.

50. Yamano, N. and Ohkawara, T., 2000. The Regional Allocation of Public Investment: Efficiency or Equity?, Journal of Regional Science 40(2), 205-229. 
Table 1. Main inputs in multi-criteria analyses used by the Planning Department of the Spanish Infrastructure Ministry

\begin{tabular}{ll}
\hline Main selection criteria & Indicators \\
\hline Economic & profitability (internal rate of return) \\
\hline Socio-Economic & population \\
& - tourism potential \\
& - mean income \\
& - existence of other relevant infrastructure \\
\hline Territorial & accessibility \\
& - territorial disparities in income and \\
& infrastructure endowment \\
& link belongs to a main route \\
\hline
\end{tabular}


Table 2. Variable definitions and data sources

\begin{tabular}{|c|c|c|c|}
\hline Variables & Definition & Geo. Scale ${ }^{1}$ & Data Source \\
\hline trunkroad & $\begin{array}{l}\text { Existing national trunk road within municipality } \\
\text { radius }\end{array}$ & NUTS V & GIS own calculations \\
\hline access & Index of potential population accessibility & NUTS V & GIS own calculations \\
\hline pop & Absolute size of population (in hundreds) & NUTS V & INE \\
\hline dagglom & $\begin{array}{l}\text { Dummy equal to one if municipality forms part of a } \\
\text { major urban agglomeration }\end{array}$ & NUTS V & GIS own calculations \\
\hline dcoast & $\begin{array}{l}\text { Dummy equal to one if municipality is at less than } \\
10 \mathrm{~km} \text { from the coast }\end{array}$ & NUTS V & GIS own calculations \\
\hline gdp_capita & $\begin{array}{l}\text { GDP/capita (in millions of } 1986 \text { constant pesetas) } \\
\text { relative to national average }\end{array}$ & NUTS III & FBBVA/Eurostat \\
\hline access_prov & $\begin{array}{l}\text { Mean province accessibility relative to national } \\
\text { average }\end{array}$ & NUTS III & GIS own calculations \\
\hline infra_capital & $\begin{array}{l}\text { Real net capital stock in transport infrastructure } \\
\text { relative to the average real net capital stock in }\end{array}$ & NUTS III & Fundación BBVA \\
\hline gdp_growth & $\begin{array}{l}\text { transport infrastructure among all provinces } \\
\text { Prior average annual \% change in GDP }\end{array}$ & NUTS III & FBBVA/Eurostat \\
\hline pop_growth & Prior average annual $\%$ change in population & NUTS V & INE \\
\hline
\end{tabular}


Table 3. Factors related to receiving a new motorway: 1983-1993

\begin{tabular}{|c|c|c|c|c|c|c|}
\hline & (1) & $(2)$ & (3) & (4) & (5) & (6) \\
\hline trunkroad & $\begin{array}{l}0.540 * * * \\
(0.007)\end{array}$ & $\begin{array}{l}0.509 * * * \\
(0.007)\end{array}$ & $\begin{array}{l}0.510 * * * \\
(0.010)\end{array}$ & $\begin{array}{l}0.509 * * * \\
(0.010)\end{array}$ & $\begin{array}{l}0.510 * * * \\
(0.010)\end{array}$ & $\begin{array}{l}0.510 * * * \\
(0.010)\end{array}$ \\
\hline access & & $\begin{array}{l}0.082 * * * \\
(0.006)\end{array}$ & $\begin{array}{l}0.082^{* * *} \\
(0.016)\end{array}$ & $\begin{array}{l}0.084 * * * \\
(0.021)\end{array}$ & $\begin{array}{l}0.083 * * * \\
(0.021)\end{array}$ & $\begin{array}{l}0.082 * * * \\
(0.021)\end{array}$ \\
\hline pop & & $\begin{array}{l}0.002 * * * \\
(0.0003)\end{array}$ & $\begin{array}{l}0.002 * * * \\
(0.0004)\end{array}$ & $\begin{array}{l}0.002^{* * *} \\
(0.0004)\end{array}$ & $\begin{array}{l}0.002 * * * \\
(0.0004)\end{array}$ & $\begin{array}{l}0.002 * * * \\
(0.0004)\end{array}$ \\
\hline dagglom & & $\begin{array}{l}0.217 * * * \\
(0.018)\end{array}$ & $\begin{array}{l}0.235^{* * *} \\
(0.022)\end{array}$ & $\begin{array}{l}0.235^{* * * *} \\
(0.023)\end{array}$ & $\begin{array}{l}0.235^{* * *} \\
(0.023)\end{array}$ & $\begin{array}{l}0.238 * * * \\
(0.023)\end{array}$ \\
\hline dcoast & & & $\begin{array}{l}-0.061 * * * \\
(0.019)\end{array}$ & $\begin{array}{l}-0.061 * * * \\
(0.019)\end{array}$ & $\begin{array}{l}-0.061 * * * \\
(0.019)\end{array}$ & $\begin{array}{l}-0.064 * * * \\
(0.019)\end{array}$ \\
\hline gdp_capita & & & $\begin{array}{c}0.013 \\
(0.011)\end{array}$ & $\begin{array}{c}0.013 \\
(0.011)\end{array}$ & $\begin{array}{c}0.013 \\
(0.011)\end{array}$ & $\begin{array}{c}0.014 \\
(0.011)\end{array}$ \\
\hline access_prov & & & & $\begin{array}{c}-0.011 \\
(0.092)\end{array}$ & $\begin{array}{r}0.005 \\
(0.110)\end{array}$ & $\begin{array}{r}-0.016 \\
(0.113)\end{array}$ \\
\hline infra_capital & & & & & $\begin{array}{c}-0.004 \\
(0.014)\end{array}$ & $\begin{array}{c}-0.001 \\
(0.014)\end{array}$ \\
\hline pop_growth & & & & & & $\begin{array}{c}0.001 \\
(0.001)\end{array}$ \\
\hline gdp_growth & & & & & & $\begin{array}{c}0.009 \\
(0.011)\end{array}$ \\
\hline Observations & 7506 & 7506 & 7506 & 7506 & 7506 & 7506 \\
\hline Adjusted $\mathrm{R}^{2}$ & 0.439 & 0.472 & 0.475 & 0.475 & 0.475 & 0.475 \\
\hline
\end{tabular}

Note: Standard errors are reported in parenthesis. In Colum (3) to (6) standard errors are corrected for clustering by Moulton's method. Significant coefficients are indicated by ***,**, *, for significance at the $1 \%, 5 \%$ and $10 \%$ level, respectively. All estimations include unreported Autonomous Community regional dummies and a constant. 
Table 4. Factors related to receiving a new motorway: 1994-2004

\begin{tabular}{|c|c|c|c|c|c|c|}
\hline & (1) & $(2)$ & (3) & (4) & (5) & (6) \\
\hline trunkroad & $\begin{array}{l}0.568 * * * \\
(0.012)\end{array}$ & $\begin{array}{l}0.542 * * * \\
(0.012)\end{array}$ & $\begin{array}{l}0.538 * * * \\
(0.016)\end{array}$ & $\begin{array}{l}0.530 * * * \\
(0.015)\end{array}$ & $\begin{array}{l}0.526^{* * *} * \\
(0.015)\end{array}$ & $\begin{array}{l}0.524 * * * \\
(0.015)\end{array}$ \\
\hline access & & $\begin{array}{l}0.065^{* * * *} \\
(0.008)\end{array}$ & $\begin{array}{l}0.069^{* * * *} \\
(0.017)\end{array}$ & $\begin{array}{l}0.118^{* * * *} \\
(0.020)\end{array}$ & $\begin{array}{l}0.120 * * * \\
(0.019)\end{array}$ & $\begin{array}{l}0.109 * * * \\
(0.019)\end{array}$ \\
\hline pop & & $\begin{array}{l}0.006^{* * * *} \\
(0.001)\end{array}$ & $\begin{array}{l}0.006^{* * * *} \\
(0.001)\end{array}$ & $\begin{array}{l}0.006^{* * * *} \\
(0.001)\end{array}$ & $\begin{array}{l}0.006^{* * *} \\
(0.001)\end{array}$ & $\begin{array}{l}0.006^{* * * *} \\
(0.001)\end{array}$ \\
\hline dagglom & & $\begin{array}{l}0.131 * * * \\
(0.028)\end{array}$ & $\begin{array}{l}0.129 * * * \\
(0.032)\end{array}$ & $\begin{array}{l}0.122 * * * \\
(0.031)\end{array}$ & $\begin{array}{l}0.116^{* * *} \\
(0.031)\end{array}$ & $\begin{array}{l}0.106^{* * *} \\
(0.030)\end{array}$ \\
\hline dcoast & & & $\begin{array}{l}-0.002 \\
(0.021)\end{array}$ & $\begin{array}{l}-0.005 \\
(0.020)\end{array}$ & $\begin{array}{l}-0.008 \\
(0.019)\end{array}$ & $\begin{array}{l}-0.016 \\
(0.019)\end{array}$ \\
\hline gdp_capita & & & $\begin{array}{l}-0.009 \\
(0.007)\end{array}$ & $\begin{array}{l}-0.004 \\
(0.007)\end{array}$ & $\begin{array}{l}-0.004 \\
(0.006)\end{array}$ & $\begin{array}{l}-0.003 \\
(0.007)\end{array}$ \\
\hline access_prov & & & & $\begin{array}{l}-0.309 * * * \\
(0.089)\end{array}$ & $\begin{array}{l}-0.411^{* * *} \\
(0.099)\end{array}$ & $\begin{array}{l}-0.395^{* * * *} \\
(0.098)\end{array}$ \\
\hline infra_capital & & & & & $\begin{array}{l}0.025 * * \\
(0.012)\end{array}$ & $\begin{array}{c}0.021 * \\
(0.012)\end{array}$ \\
\hline pop_growth & & & & & & $\begin{array}{l}0.007 * * * \\
(0.002)\end{array}$ \\
\hline gdp_growth & & & & & & $\begin{array}{l}-0.010 \\
(0.010)\end{array}$ \\
\hline Observations & 7008 & 7008 & 7008 & 7008 & 7008 & 7008 \\
\hline Adjusted $\mathrm{R}^{2}$ & 0.284 & 0.305 & 0.306 & 0.312 & 0.316 & 0.317 \\
\hline
\end{tabular}

Note: Standard errors are reported in parenthesis. In Colum (3) to (6) standard errors are corrected for clustering by Moulton's method. Significant coefficients are indicated by $* * *, * *$, , for significance at the $1 \%, 5 \%$ and $10 \%$ level, respectively. All estimations include unreported Autonomous Community regional dummies and a constant. 
Table 5. Factors related to receiving a new motorway in the plan: 1983-1993

\begin{tabular}{|c|c|c|c|c|c|c|}
\hline & $(1)$ & $(2)$ & (3) & (4) & (5) & (6) \\
\hline trunkroad & $\begin{array}{l}0.547 * * * \\
(0.007)\end{array}$ & $\begin{array}{l}0.529 * * * \\
(0.007)\end{array}$ & $\begin{array}{l}0.529 * * * \\
(0.009)\end{array}$ & $\begin{array}{l}0.529 * * * \\
(0.009)\end{array}$ & $\begin{array}{l}0.530 * * * \\
(0.008)\end{array}$ & $\begin{array}{l}0.531 * * * \\
(0.008)\end{array}$ \\
\hline access & & $\begin{array}{l}0.045^{* * *} \\
(0.005)\end{array}$ & $\begin{array}{l}0.046^{* * *} \\
(0.014)\end{array}$ & $\begin{array}{l}0.048 * * * \\
(0.017)\end{array}$ & $\begin{array}{l}0.047 * * * \\
(0.017)\end{array}$ & $\begin{array}{l}0.048 * * * \\
(0.017)\end{array}$ \\
\hline pop & & $\begin{array}{l}0.002 * * * \\
(0.0003)\end{array}$ & $\begin{array}{l}0.002 * * * \\
(0.0003)\end{array}$ & $\begin{array}{l}0.002 * * * \\
(0.0003)\end{array}$ & $\begin{array}{l}0.002 * * * \\
(0.0003)\end{array}$ & $\begin{array}{l}0.002 * * * \\
(0.0003)\end{array}$ \\
\hline dagglom & & $\begin{array}{l}-0.019 \\
(0.016)\end{array}$ & $\begin{array}{l}-0.006 \\
(0.020)\end{array}$ & $\begin{array}{l}-0.007 \\
(0.020)\end{array}$ & $\begin{array}{l}-0.004 \\
(0.020)\end{array}$ & $\begin{array}{l}-0.0003 \\
(0.020)\end{array}$ \\
\hline dcoast & & & $\begin{array}{l}-0.041^{* *} \\
(0.017)\end{array}$ & $\begin{array}{l}-0.041 * * \\
(0.017)\end{array}$ & $\begin{array}{l}-0.039 * * \\
(0.017)\end{array}$ & $\begin{array}{l}-0.040 * * \\
(0.017)\end{array}$ \\
\hline gdp_capita & & & $\begin{array}{c}0.002 \\
(0.009)\end{array}$ & $\begin{array}{c}0.003 \\
(0.009)\end{array}$ & $\begin{array}{c}0.004 \\
(0.009)\end{array}$ & $\begin{array}{c}0.005 \\
(0.009)\end{array}$ \\
\hline access_prov & & & & $\begin{array}{l}-0.012 \\
(0.081)\end{array}$ & $\begin{array}{c}0.074 \\
(0.094)\end{array}$ & $\begin{array}{c}0.059 \\
(0.096)\end{array}$ \\
\hline infra_capital & & & & & $\begin{array}{r}-0.020 * \\
(0.012)\end{array}$ & $\begin{array}{c}-0.018 \\
(0.012)\end{array}$ \\
\hline pop_growth & & & & & & $\begin{array}{l}-0.001 \\
(0.001)\end{array}$ \\
\hline gdp_growth & & & & & & $\begin{array}{c}0.005 \\
(0.009)\end{array}$ \\
\hline Observations & 7503 & 7503 & 7503 & 7503 & 7503 & 7503 \\
\hline Adjusted $\mathrm{R}^{2}$ & 0.505 & 0.505 & 0.514 & 0.514 & 0.515 & 0.515 \\
\hline
\end{tabular}

Note: Standard errors are reported in parenthesis. In Colum (3) to (6) standard errors are corrected for clustering by Moulton's method. Significant coefficients are indicated by ***,**, *, for significance at the $1 \%, 5 \%$ and $10 \%$ level, respectively. All estimations include unreported Autonomous Community regional dummies and a constant. 
Table 6. Factors related to receiving a new motorway in the plan: 1994-2004

\begin{tabular}{|c|c|c|c|c|c|c|}
\hline & (1) & $(2)$ & (3) & (4) & (5) & (6) \\
\hline trunkroad & $\begin{array}{l}0.622 * * * \\
(0.013)\end{array}$ & $\begin{array}{l}0.603 * * * \\
(0.014)\end{array}$ & $\begin{array}{l}0.601 * * * \\
(0.019)\end{array}$ & $\begin{array}{l}0.586^{* * *} * \\
(0.017)\end{array}$ & $\begin{array}{l}0.582 * * * \\
(0.017)\end{array}$ & $\begin{array}{l}0.585 * * * \\
(0.017)\end{array}$ \\
\hline access & & $\begin{array}{l}0.068 * * * \\
(0.009)\end{array}$ & $\begin{array}{l}0.072 * * * \\
(0.022)\end{array}$ & $\begin{array}{l}0.158 * * * \\
(0.023)\end{array}$ & $\begin{array}{l}0.159 * * * \\
(0.023)\end{array}$ & $\begin{array}{l}0.148 * * * \\
(0.023)\end{array}$ \\
\hline pop & & $\begin{array}{l}0.005^{* * *} * \\
(0.001)\end{array}$ & $\begin{array}{l}0.005^{* * * *} \\
(0.001)\end{array}$ & $\begin{array}{l}0.004^{* * *} * \\
(0.001)\end{array}$ & $\begin{array}{l}0.004^{* * *} \\
(0.001)\end{array}$ & $\begin{array}{l}0.004^{* * *} * \\
(0.001)\end{array}$ \\
\hline dagglom & & $\begin{array}{l}-0.028 \\
(0.029)\end{array}$ & $\begin{array}{l}-0.023 \\
(0.034)\end{array}$ & $\begin{array}{l}-0.035 \\
(0.032)\end{array}$ & $\begin{array}{l}-0.039 \\
(0.032)\end{array}$ & $\begin{array}{l}-0.045 \\
(0.032)\end{array}$ \\
\hline dcoast & & & $\begin{array}{l}-0.022 \\
(0.026)\end{array}$ & $\begin{array}{l}-0.028 \\
(0.023)\end{array}$ & $\begin{array}{l}-0.030 \\
(0.022)\end{array}$ & $\begin{array}{l}-0.038 * \\
(0.022)\end{array}$ \\
\hline gdp_capita & & & $\begin{array}{l}-0.007 \\
(0.009)\end{array}$ & $\begin{array}{c}0.001 \\
(0.008)\end{array}$ & $\begin{array}{c}0.001 \\
(0.008)\end{array}$ & $\begin{array}{l}-0.002 \\
(0.008)\end{array}$ \\
\hline access_prov & & & & $\begin{array}{l}-0.521 * * * \\
(0.101)\end{array}$ & $\begin{array}{l}-0.608 * * * \\
(0.118)\end{array}$ & $\begin{array}{l}-0.589 * * * \\
(0.116)\end{array}$ \\
\hline infra_capital & & & & & $\begin{array}{l}0.020 \\
(0.015)\end{array}$ & $\begin{array}{c}0.022 \\
(0.015)\end{array}$ \\
\hline pop_growth & & & & & & $\begin{array}{l}0.007 * * * \\
(0.002)\end{array}$ \\
\hline gdp_growth & & & & & & $\begin{array}{c}0.016 \\
(0.012)\end{array}$ \\
\hline Observations & 7038 & 7038 & 7038 & 7038 & 7038 & 7038 \\
\hline Adjusted $\mathrm{R}^{2}$ & 0.251 & 0.261 & 0.261 & 0.277 & 0.278 & 0.281 \\
\hline
\end{tabular}

Note: Standard errors are reported in parenthesis. In Colum (3) to (6) standard errors are corrected for clustering by Moulton's method. Significant coefficients are indicated by $* * *, * * *$, for significance at the $1 \%, 5 \%$ and $10 \%$ level, respectively. All estimations include unreported Autonomous Community regional dummies and a constant. 
Figure 1. Extension of the motorway network in Spain: 1970-2009

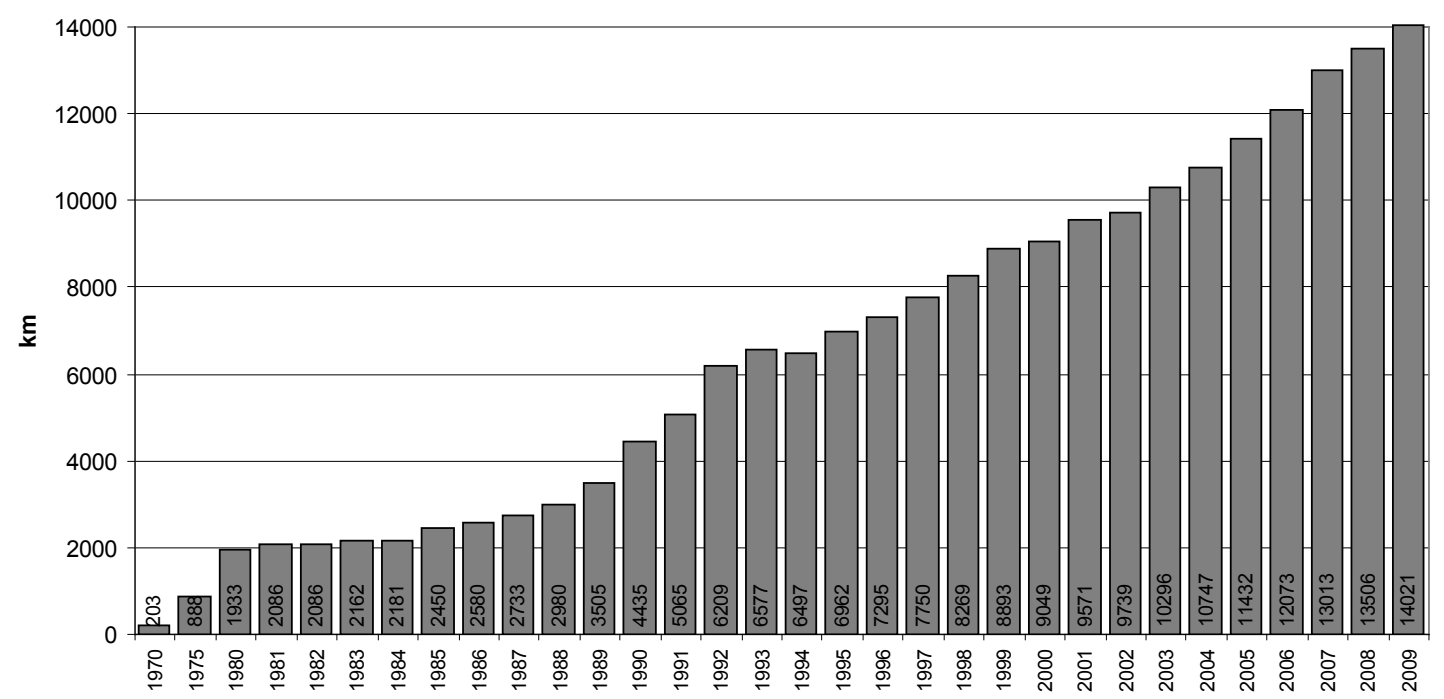

Source: Anuario estadístico, Fomento, various years. Note in 1994 a new inventory for national roads was drawn up and some of the motorways became classified as dual-carriage roads. 
Figure 2. The National Road Plan - "Plan General de Carreteras"1984-1991

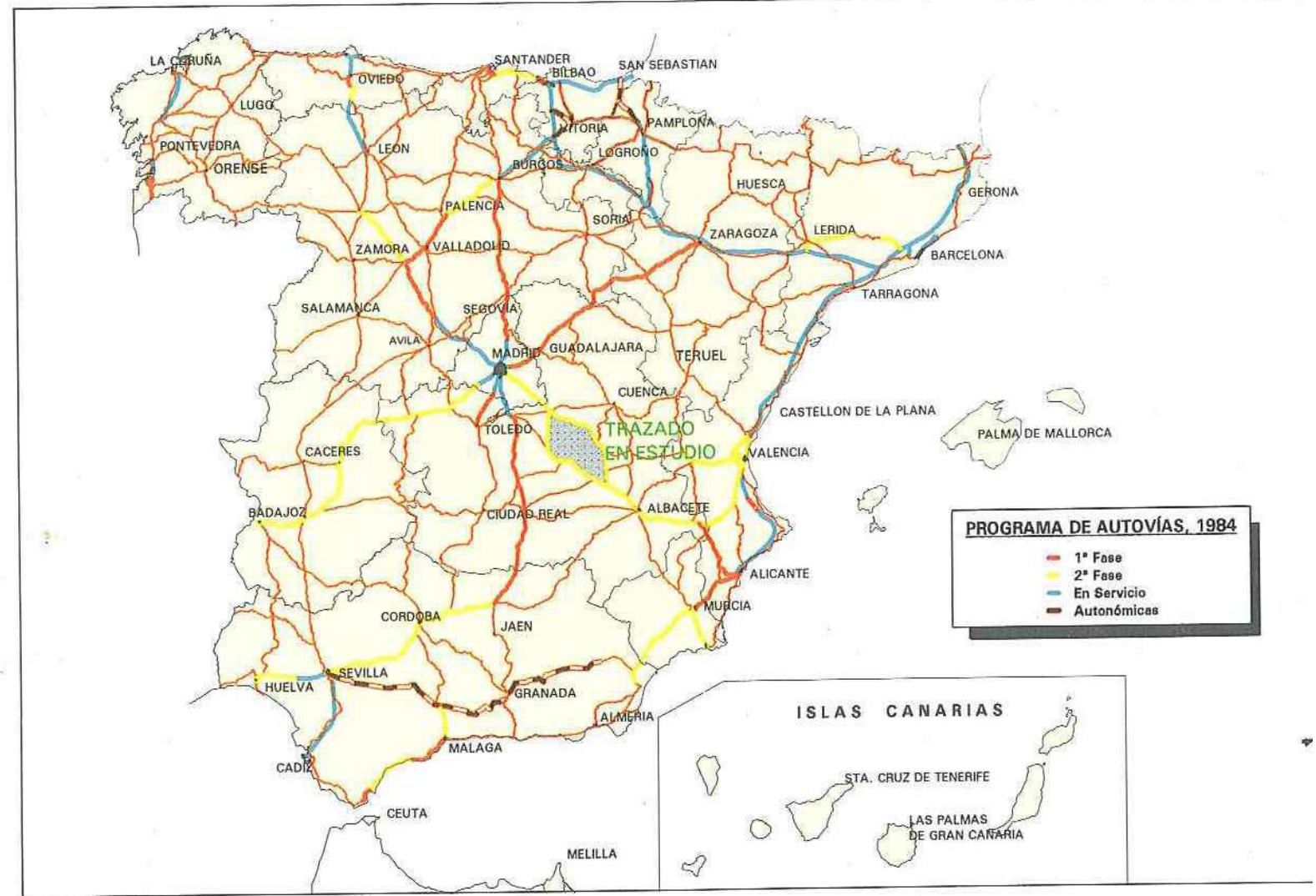

Source: MOPT (1993): Note: bold red lines are free motorways that were planned to be constructed in the first phase of the programme; bold yellow lines are free motorways that were planned to be constructed in the second phase of the programme; blue bold lines are motorways that were in service; black-red bold lines are motorways that were to be built by the regional governments. 
Figure 3. Principal designated post routes: Thomas Lopez 1760

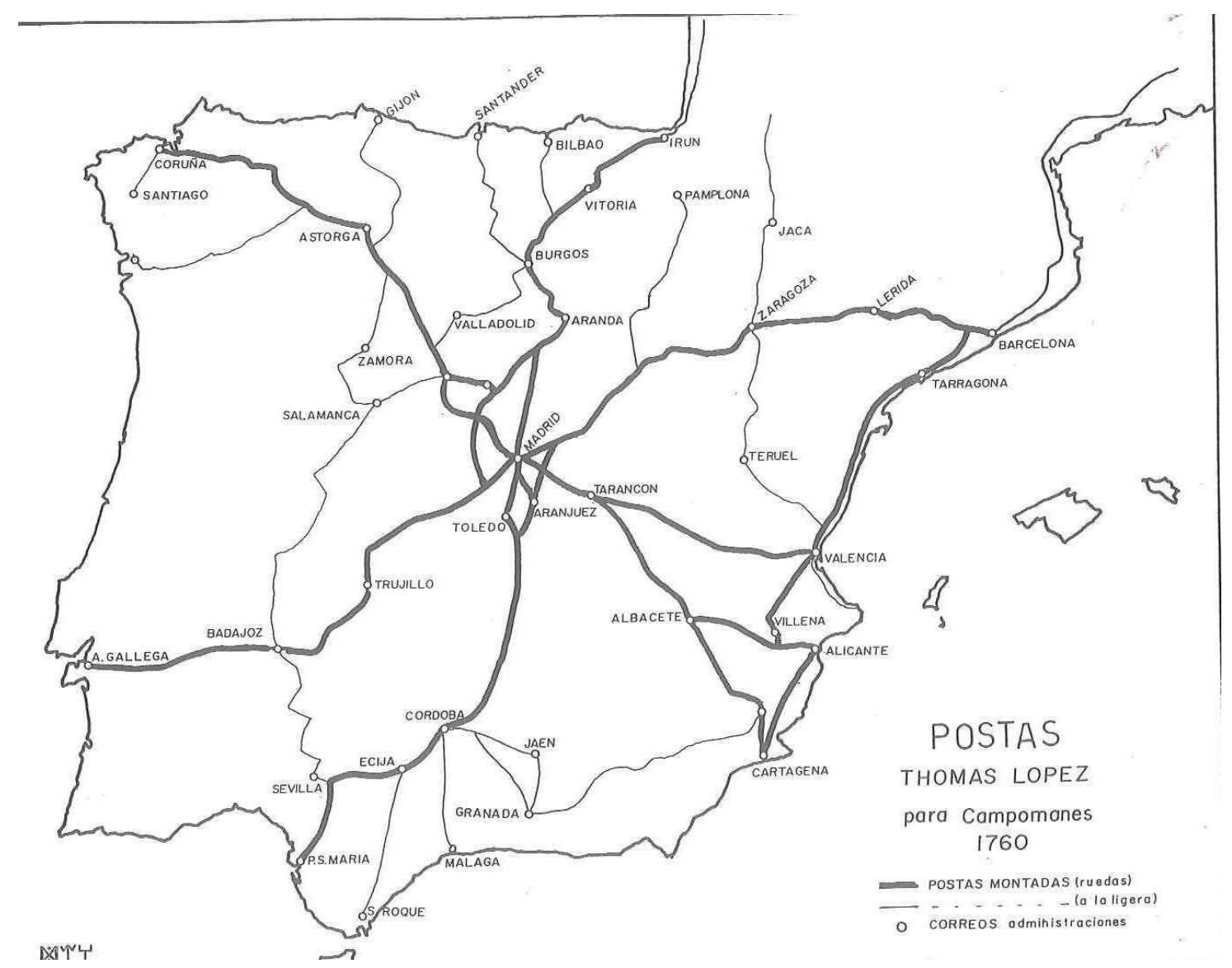

Source: reproduced from Menéndez-Pidal (1992). Note: bold black lines are the main postal routes. 
Figure 4. The Infrastructure Master Plan - “Director de Infrastructuras”(PDI): 1993-2007

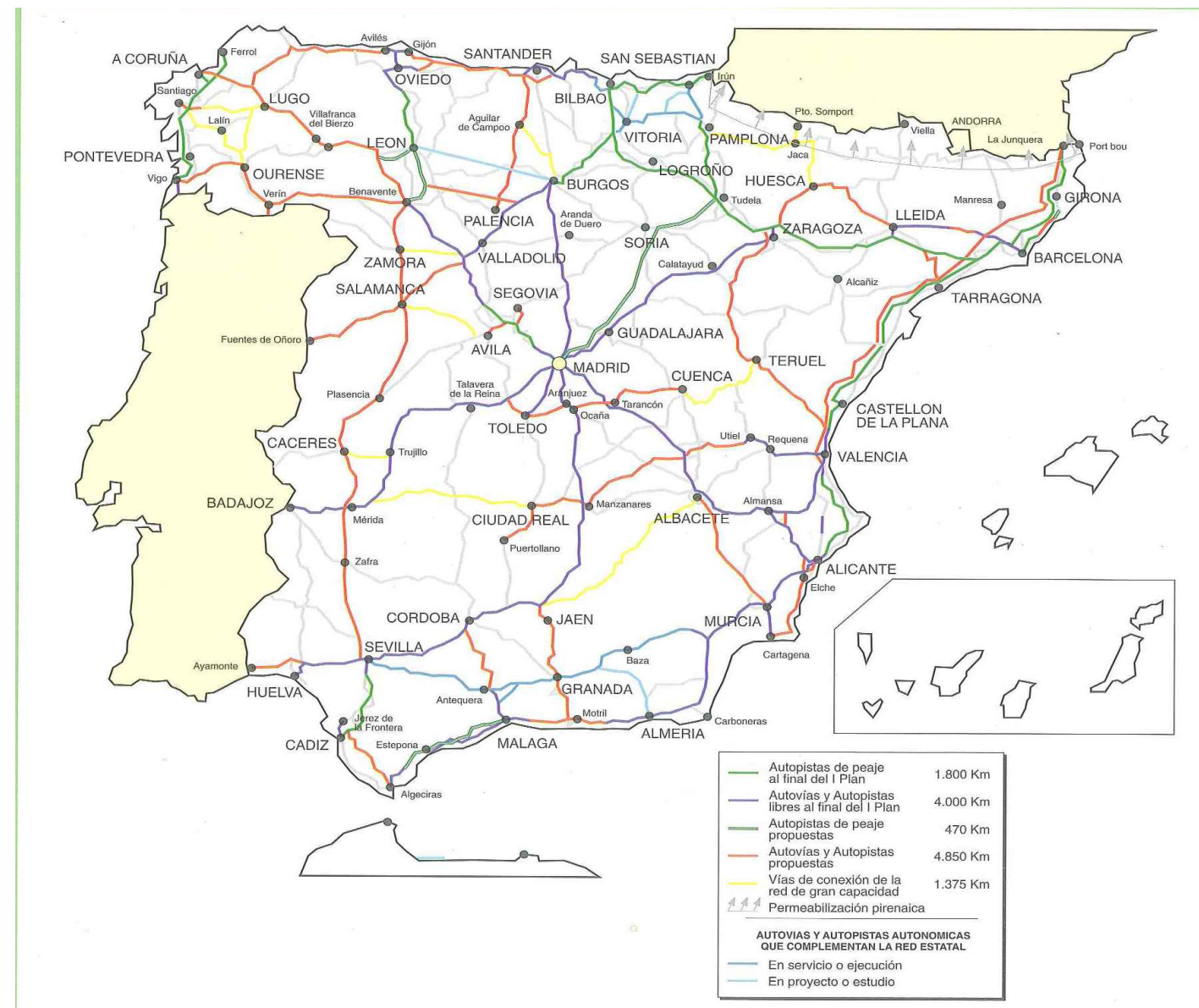

Source: MOPT (1994). Notes: Light green: toll motorways in service at the end of the previous National Road Plan; dark blue: free motorways in service at the end of the previous National Road Plan; dark green: national toll motorways planned; red: national free motorways planned; yellow: connections between high-capacity roads; mid-blue: regional motorways in service at the end of the previous National Road Plan, light blue: planned regional motorways. 
1. Holl, A., Pardo, R. \& Rama, R. Spatial patterns of adoption of just-in-time manufacturing.

2. Brooks, C. \& Calzada, I. On policy feedback: insights from survey experiments.

3. Moreno, L. Multilevel citizens, new social risks and regional welfare.

4. Moreno, L., Calzada,I., Moreno-Fuentes, F. J. Mapping the axiology of european welfare.

5. Holl, A. Factors influencing the location of new motorways: the large scale motorway building in Spain 